bioRxiv preprint doi: https://doi. org/10.1101/2020.04.14.033944 this version posted April 15,2020 . The copyright holder for this preprint

(which was not certified by peer review) is the author/funder, who has granted bioRxiv a license to display the preprint in perpetuity. It is made available under aCC-BY-NC-ND 4.0 International license.

\title{
Contrasting effects of chronic lithium, haloperidol and olanzapine exposure on synaptic clusters in the rat prefrontal cortex
}

Els F. Halff ${ }^{1,2}$, Marie-Caroline Cotel ${ }^{3}$, Sridhar Natesan ${ }^{1,2,4}$, Richard McQuade ${ }^{5}$, Chris J. Ottley ${ }^{6}$, Deepak P. Srivastiva $^{3,8}$, Oliver D. Howes ${ }^{1,2,4,7,8}$, Anthony C. Vernon ${ }^{3,8 *}$.

${ }^{1}$ Department of Psychosis Studies, Institute of Psychiatry, Psychology and Neuroscience, King's College London, De Crespigny Park, London, SE5 8AF, UK

${ }^{2}$ Psychiatric Imaging group, MRC London Institute of Medical Sciences, Du Cane Road, London W12 0NN, UK

${ }^{3}$ Department of Basic and Clinical Neuroscience, Institute of Psychiatry, Psychology and Neuroscience, Maurice Wohl Clinical Neuroscience Institute, King's College London, 5 Cutcombe Road, London SE5 9RT, UK

${ }^{4}$ Psychiatric Imaging group, Institute of Clinical Sciences, Faculty of Medicine, Imperial College London, Hammersmith Hospital, 72 Du Cane Road, London W12 0HS, UK

${ }^{5}$ Psychobiology Research Group, School of Neurology, Neurobiology and Psychiatry, Newcastle University, NE2 4HH, Newcastle upon Tyne, UK

${ }^{6}$ Department of Earth Sciences, Durham University, Durham, DH1 3LE, UK.

${ }^{7}$ South London and Maudsley NHS Foundation Trust, Camberwell, London, UK

${ }^{8}$ MRC Centre for Neurodevelopmental Disorders, King's College London, London SE1 1UL, UK

*Corresponding author: anthony.vernon@kcl.ac.uk

\section{Author contributions:}

Conceptualization: ACV, SN, ODH.

Methodology: EFH, MCC, SN, ACV, RM, CJO.

Experimental Investigation and Data Analysis: EFH, ACV, RM, CJO

Contribution of Unique Resources: $\mathrm{ODH}, \mathrm{ACV}$

Funding: ODH, ACV

Writing - original draft: EFH, ACV

Writing - editing and revision: $\mathrm{EFH}, \mathrm{ACV}, \mathrm{RM}, \mathrm{ODH}, \mathrm{SN}, \mathrm{DPS}$

Supervision: ACV, SN, ODH 


\begin{abstract}
The pathophysiology of the majority of neuropsychiatric disorders, including schizophrenia and mood disorders, involves synaptic dysfunction and/or loss, manifesting as lower levels of several presynaptic and postsynaptic marker proteins. Whether chronic exposure to antipsychotic drugs may contribute to this pattern of synaptic loss remains controversial. In contrast, the mood stabiliser lithium has shown to exhibit neurotrophic actions and is thought to enhance synapse formation. Whilst these data are not unequivocal, they suggest that antipsychotic drugs and lithium have contrasting effects on synapse density. We therefore investigated the effect of chronic exposure to lithium and to two different antipsychotics, haloperidol and olanzapine, on presynaptic Synaptic Vesicle glycoprotein 2A (SV2A) and postsynaptic Neuroligin (NLGN) clusters in the rat frontal cortex. Chronic exposure (28 days) to haloperidol $(0.5 \mathrm{mg} / \mathrm{kg} / \mathrm{d})$ or olanzapine $(7.5$ $\mathrm{mg} / \mathrm{kg} / \mathrm{d}$ ) had no effect on either SV2A or NLGN clusters and no overall effect on synaptic clusters. In contrast, chronic lithium exposure ( $2 \mathrm{mmol} / \mathrm{L}$ eq./d) significantly increased NLGN cluster density as compared to vehicle, but did not affect either SV2A or total synaptic clusters. These data are consistent with and extend our prior work, confirming no effect of either antipsychotics or lithium on SV2A clustering, but suggest contrasting effects of these drugs on the post-synapse. Although caution needs to be exerted when extrapolating results from animals to patients, these data provide clarity with regard to the effect of antipsychotics and lithium on synaptic markers, thus facilitating discrimination of drug from illness effects in human studies of synaptic pathology in psychiatric disorders.
\end{abstract}

Key words: antipsychotics, lithium, synaptic density, SV2A, schizophrenia, bipolar disorder 
bioRxiv preprint doi: https://doi.org/10.1101/2020.04.14.033944; this version posted April 15, 2020. The copyright holder for this preprint (which was not certified by peer review) is the author/funder, who has granted bioRxiv a license to display the preprint in perpetuity. It is made available under aCC-BY-NC-ND 4.0 International license.

\section{Introduction}

Schizophrenia (SCZ) and Bipolar Disorder (BD) are psychiatric disorders that affect approximately $0.5 \%$ and $1 \%$ of the global population, respectively (WHO). For each of these disorders there is accumulating evidence that synaptic dysfunction is a hallmark of the pathophysiology of the disease. Neuroimaging and post-mortem studies of individuals with SCZ or BD show reduced brain volume and spine density, particularly in the prefrontal and anterior cingulate cortex and hippocampus relative to healthy controls ${ }^{1-4}$. These changes coincide with reduced protein and/or mRNA levels of various synaptic markers ${ }^{5-11}$. Whereas the majority of these data were derived from post-mortem human material, the recent development of the UCB-J PET tracers, which specifically interact with the presynaptic Synaptic Vesicle glycoprotein 2A (SV2A), has enabled visualisation of pre-synaptic terminal density in the living human brain ${ }^{12-14}$. SV2A is thought to play a role in neurotransmitter release and vesicle recycling ${ }^{15-18}$, and, due its localisation at both inhibitory and excitatory synapses throughout the brain, is considered as a proxy for overall synaptic density. Consistent with the aforementioned post-mortem evidence, studies using $\left[{ }^{11} \mathrm{C}\right]-\mathrm{UCB}-\mathrm{J}$ PET imaging provide evidence for a reduction in SV2A binding in chronic $\mathrm{SCZ}^{19}$. Whilst there is also evidence for reduced SV2A ligand binding in major depressive disorder ${ }^{16}$, data for BD is as yet lacking.

Our recent study in chronic SCZ patients also demonstrated that total SV2A protein levels and [ $\left.{ }^{3} \mathrm{H}\right]-\mathrm{UCB}$ $\mathrm{J}$ radioligand specific binding in the rat frontal cortex were unaffected by chronic exposure to two different antipsychotic drugs (APD) ${ }^{19}$. These data suggest that the reduced SV2A ligand binding observed in patients is related to SCZ pathophysiology rather than an effect of antipsychotic treatment. In contrast, there is no data concerning the effect of mood stabilising drugs used in the treatment of BD such as lithium (Li) on SV2A per se. Importantly, as SV2A is located in pre-synaptic terminals, analysis of SV2A alone does not fully address the question of whether exposure to either antipsychotic drugs or Li affects synaptic density or not. In this context, several studies investigating the effect of antipsychotic and mood-stabilising medication on the animal brain provide evidence to suggest that synaptic changes may occur upon administration of these drugs. These include altered spine density ${ }^{20}$, dendritic branching ${ }^{21}$, and altered expression of synaptic protein markers such as Synapsin, SNAP-25, Synaptophysin, and PSD-95 $5^{22-24}$, however SV2A was not assessed in these studies. In earlier work we demonstrated contrasting effects of the antipsychotic drugs Haloperidol (HAL) and Olanzapine (OLZ) compared to the mood stabiliser lithium (Li) on rat cortical grey matter volume, showing an increase upon Li treatment but reduced cortical volume upon exposure to HAL and OLZ ${ }^{25,26}$. To gain further insight into the effect of psychotropic medication on synaptic density, we therefore investigated the effects of HAL, OLZ, and Li treatments on SV2A and Neuroligin (NLGN) clusters as global pre- and postsynaptic marker, respectively. We hypothesised that cluster count would be unaffected by chronic exposure to either HAL or OLZ, concurrent with our earlier data ${ }^{19}$, however we anticipated that chronic exposure to Li, which has been suggested to have neurotrophic and neuroprotective effects ${ }^{21,27}$, would lead to an increase in synaptic clusters. Our research provides one of the first investigations into the effect of these different psychotropic medications on SV2A clusters. 
bioRxiv preprint doi: https://doi.org/10.1101/2020.04.14.033944; this version posted April 15, 2020. The copyright holder for this preprint (which was not certified by peer review) is the author/funder, who has granted bioRxiv a license to display the preprint in perpetuity. It is made available under aCC-BY-NC-ND 4.0 International license.

\section{Materials and Methods}

Animals

Animal experiments were carried out in accordance with the Home Office Animals (Scientific Procedures) Act (1986) and European Union (EU) Directive 2010/63/EU, with the approval of the local Animal Welfare and Ethical Review Body (AWERB) panel at King's College London (KCL). Male Sprague-Dawley rats (Charles River UK Ltd, Margate, UK), initial body weight 220-270 gram (6-10 weeks of age) were housed four per cage in conventional plastic cages ( $38 \times 59$ × $24 \mathrm{~cm}$, Tecniplast, UK) containing sawdust, paper sizzle nest and cardboard tunnels. Animals were maintained under a 12-hour light/dark cycle (07.00 lights on) with food and water available ad libitum. Room temperature and humidity were maintained at $21 \pm 2{ }^{\circ} \mathrm{C}$ and $55 \pm$ $5 \%$, respectively. Animals were habituated for a minimum of 7 days before experimental procedures.

\section{Experimental Design (animals)}

Two separate batches of animals received continuous administration of psychotropic medication using osmotic minipumps (Alzet Model 2ML4; Alzet, Cupertino, CA, USA) for 28 days (equivalent to approximately 2.5 human years based on 11.8 rat days as equivalent to 1 human year ${ }^{28}$ ). Specifically, cohort 1 comprised animals of initial body weight 240-270 gram (9-10 weeks of age), treated with a common vehicle ( $\beta$ hydroxypropylcyclodextrin, $20 \% \mathrm{wt} / \mathrm{vol}$, acidified by ascorbic acid to $\mathrm{pH} 6 ; \mathrm{n}=11), 0.5 \mathrm{mg} / \mathrm{kg} / \mathrm{day}$ haloperidol (HAL; $\mathrm{n}=11$ ), or $2 \mathrm{mmol} / \mathrm{L}$ equiv/kg/day lithium chloride ( $\mathrm{Li} ; \mathrm{n}=10)$. Cohort 2 comprised animals of initial body weight 220-240 gram (6-7 weeks of age) treated with vehicle ( $\mathrm{n}=4)$, or $7.5 \mathrm{mg} / \mathrm{kg} /$ day olanzapine (OLZ; $\mathrm{n}=12$ ) (all chemicals from Sigma-Aldrich, Gillingham, UK). Blood plasma levels achieved using these doses and delivery by osmotic pumps are consistent with clinically comparable dopamine D2 receptor (D2R) occupancy and plasma levels ${ }^{25,26,29}$. With the exception of Li-treated animals, data reported in this study is derived from the same animals as those used in our previous study ${ }^{19}$.

Minipumps filled with drug or vehicle solutions were inserted subcutaneously on the back flank under isoflurane anaesthesia (5\% induction, 1.5\% maintenance delivered in an 80/20\% medical air/oxygen mix). Weight was monitored daily in the week following surgery, and twice a week in the following weeks. Dyskinetic behaviour, i.e. vacuous chewing movements (VCMs) were measured at 2 and 4 weeks post surgery, during a 2-minute period following a 1-minute habituation phase outside the home cage. VCMs are stereotypical motor behaviours that commonly develop in animals treated with antipsychotics ${ }^{30,31}$ and are considered a proxy measure for tardive dyskinesia (TD) observed in patients undergoing chronic antipsychotic treatment. Animals undergoing Li treatment were given access to $0.9 \%$ saline instead of tap water to minimise hyponatremic properties of $\mathrm{Li}^{32}$. 
bioRxiv preprint doi: https://doi.org/10.1101/2020.04.14.033944; this version posted April 15, 2020. The copyright holder for this preprint (which was not certified by peer review) is the author/funder, who has granted bioRxiv a license to display the preprint in perpetuity. It is made available under aCC-BY-NC-ND 4.0 International license.

\section{Post-mortem tissue handling and blood plasma analysis}

After 28 days of administration, animals were terminally anaesthetised by injection of sodium pentobarbital $(60 \mathrm{mg} / \mathrm{kg}$, intraperitoneal) and culled by cardiac perfusion using heparinised $(12.5 \mathrm{U} / \mathrm{ml})$ ice-cold PBS. In order to prevent masking of synaptic target proteins and obtain a better quality of immunostaining ${ }^{33,34}$, animals were not perfusion-fixed. Following PBS perfusion, brains were extracted, hemisected and post-fixed overnight in $4 \%$ PFA at $4{ }^{\circ} \mathrm{C}$. Brain hemispheres were then washed once in PBS, incubated in PBS-buffered $30 \%$ sucrose solution for $48 \mathrm{~h}$ at $4{ }^{\circ} \mathrm{C}$, and then snap-frozen on dry ice and stored at $-70^{\circ} \mathrm{C}$ until further processing for immunostaining.

At termination a blood sample was collected for estimation of drug levels. HAL and OLZ levels were commercially measured using tandem mass spectrometry (Cyprotex, Macclesfield, UK); Li levels were measured on an Thermo Scientific X-Series 2 ICP-MS (Durham University, Durham, UK) optimised for sensitivity and minimal oxide interferences, using an external calibration curve of 10, 25, 50 and $100 \mathrm{ppb}$ standards (Romil, Cambridge, UK). Good agreement was seen between both Li 6 and 7 isotopes indicating that spectral interferences were minimal.

\section{Fluorescence immunostaining}

The left hemisphere of each animal was serially sectioned (30 $\mu \mathrm{m}$-thick coronal sections, interval 1/12, 360 $\mu \mathrm{m}$ spacing between sections within a series) on a cryostat at $-18^{\circ} \mathrm{C}$ and stored in tissue cryoprotection solution ( $25 \%$ glycerol, $30 \%$ ethylene glycol, $45 \% 1 \times \mathrm{PBS} \mathrm{pH} 7.4,0.05 \%$ azide) at $-20^{\circ} \mathrm{C}$ until further processing. Freefloating sections from each brain in each group were washed for $10 \mathrm{~min}$ in phosphate buffer (PB; $0.1 \mathrm{M})$ and $2 \times 10 \mathrm{~min}$ in PBS. For antigen retrieval sections were incubated for $10-15 \mathrm{mins}$ in $10 \mathrm{mM}$ sodium citrate $(\mathrm{pH}$ 6.2) at RT, followed by a $15 \mathrm{~min}$ incubation in pre-heated $10 \mathrm{mM}$ sodium citrate (pH 6.2) in a water-bath at $78^{\circ} \mathrm{C}$. Sections were then allowed to cool down to RT in the same solution while gently shaking for $30 \mathrm{~min}$. Sections were then washed twice $(2 \times 5 \mathrm{~min})$ in PBS supplemented with $0.05 \%$ Triton-X100 and incubated for $3-4 \mathrm{~h}$ in blocking solution (10\% Normal Goat Serum, 1.5\% BSA, 0.3\% Triton-X100 in PBS), followed by overnight incubation at $4^{\circ} \mathrm{C}$ with primary antibody diluted in blocking solution $(1: 1000$ Rabbit- $\alpha-S V 2 \mathrm{~A}$, Abcam ab32942, Cambridge, UK; 1:300 Mouse- $\alpha$-Neuroligin1/2/3/4, Synaptic Systems 129211, Göttingen, Germany). Sections were then washed in PBS (3x10 min) and incubated for $2 \mathrm{~h}$ in secondary antibody diluted in blocking solution (1:1000 Goat- $\alpha$-mouse AlexaFluor488, abcam ab150113; 1:1000 Goat- $\alpha$-rabbit AlexaFluor555, abcam ab150090) and washed again in PBS (4x10 min). Finally, sections were mounted on Superfrost Plus slides (ThermoFisher Scientific, UK), and air-dried at RT for $1 \mathrm{~h}$ before coverslipping with mounting medium containing DAPI (Vectashield; Vector Laboratories, Peterborough, UK). 
bioRxiv preprint doi: https://doi.org/10.1101/2020.04.14.033944; this version posted April 15, 2020. The copyright holder for this preprint (which was not certified by peer review) is the author/funder, who has granted bioRxiv a license to display the preprint in perpetuity. It is made available under aCC-BY-NC-ND 4.0 International license.

\section{Confocal image acquisition and analysis}

Overview images of fluorescent staining in brain sections were acquired in automated batch mode on a VS120L100-W slide scanner (Olympus, UK) and 4x lens objective. Confocal images for quantification of synaptic clusters were acquired at the Wohl Cellular Imaging Centre using an Inverted Spinning Disk confocal microscope (Nikon, Japan) and 60x oil immersion lens objective (NA 1.4). Images were 102.65 x $102.65 \mu \mathrm{m}$ in size (512 x 512 pixels), acquired as a stack spanning 6-10 $\mu \mathrm{m}$, at an interval of $0.3 \mu \mathrm{m}$. Image stacks were acquired from 4-5 consecutive sections containing the pre-specified brain regions, either the PFC, (Bregma +4.2 to $+2.5 \mathrm{~mm}, 6$ stacks per section of which 3 in layer II/III and 3 in layer V) or the ACC (Bregma +2.3 to $+0.0 \mathrm{~mm}, 4$ stacks per section of which 2 in layer II/III and 2 in layer V). Synaptic clusters were analysed in ImageJ (https://imagej.net/Welcome), using a previously published macro ${ }^{35}$ that we adapted for our images and analysis requirements. In brief, the macro performs the following operations: 3 consecutive optical sections (equating $0.9 \mu \mathrm{m}$ total thickness) within each image stack were manually selected based on quality of staining and contrast in the image and were then combined by maximum intensity projection. After background correction using a rolling ball with radius of $5 \mu \mathrm{m}$, the image was thresholded automatically using the "Moments Dark" algorithm. The thresholded image for each channel was used as a mask to measure cluster count, size and staining intensity within the clusters in the original image. Clusters smaller than $0.12 \mu \mathrm{m}^{2}$ and larger than $5 \mu \mathrm{m}^{2}$ (SV2A) or larger than $2.4 \mu \mathrm{m}^{2}$ (NLGN) were excluded. Overlap was calculated by dilating clusters in the thresholded images of each channel by 1 pixel on all sides and overlaying both dilated masks. Overlapping clusters smaller than $0.12 \mu \mathrm{m}^{2}$ (i.e. 3 pixels) were excluded.

\section{Statistical analysis}

Statistical analyses were performed using Prism version 8 (GraphPad Software, La Jolla, California, USA). Samples sizes were based on prior studies ${ }^{19,25,26}$. Two animals (one VEH-treated and one OLZ-treated) were excluded from cluster analysis on the basis of sub-optimal saline perfusion of the brain, which negatively impacted on staining quality. Data were tested for statistical outliers based on ROUT test $(0.5 \%)$ but no outliers were identified. Data were tested for normal distribution using the Shapiro-Wilk test. Scores for VCMs and immunostaining data were analysed by two-way ANOVA, assessing treatment, time, and treatment $\mathrm{x}$ time interaction (VCM), or treatment, region, and treatment $\mathrm{x}$ region interaction (immunostaining), with post-hoc Bonferroni's multiple comparison test where appropriate. Linear correlation analysis was computed based on Pearson's correlation coefficient (2-tailed). Researchers were blinded to the treatment groups during sample preparation, imaging and image analysis. 


\section{Results}

\section{Behavioural analysis and blood plasma levels}

Following osmotic pump implantation, rats were monitored for weight loss or gain. All animals gained weight comparably with no significant differences between drug treatments and their respective control groups (Supplementary Figure S1A,B).

Administration of HAL, OLZ or Li by osmotic pump achieved plasma levels (mean \pm SD) of $3.03 \pm 0.94$ $\mathrm{ng} / \mathrm{mL}$ for $\mathrm{HAL} ; 15.5 \pm 5.54 \mathrm{ng} / \mathrm{mL}$ for OLZ and $0.3 \pm 0.04 \mathrm{mmol} / \mathrm{L}$ for $\mathrm{Li}$, respectively.

Vacuous chewing movements (VCMs) were measured at 2 and 4 weeks after the start of drug exposure. Rats exposed to HAL or OLZ, but not Li, showed a statistically significant increase in VCMs as compared to their respective control groups (Supplementary Figure S1C,D; C, main effect of treatment: F(2,29)=17.18, p<0.001, $\eta_{\mathrm{p}}{ }^{2}=0.55$; D, main effect of treatment: $\left.\mathrm{F}(1,15)=11.33, \mathrm{p}<0.01, \eta_{\mathrm{p}}{ }^{2}=0.60\right)$. There was no effect of time or treatment $\mathrm{x}$ time interaction on VCM count. There was also no correlation between HAL or OLZ plasma level and the number of VCMs (Supplementary Figure S1E,F), consistent with our prior work ${ }^{25}$.

\section{Effect of Haloperidol and Lithium treatment on synaptic markers}

Guided by our previous observation of contrasting effects of HAL and Li on rat cortical volumes, as measured using $\mathrm{MRI}^{26}$, as well as the hypothesis that APDs do not affect SV2A cluster density ${ }^{19}$, whereas Li may show a neurotrophic effect, we investigated the effects of these two treatments on both pre- and postsynaptic staining in the rat prefrontal cortex (PFC) and anterior cingulate cortex (ACC) (Fig.1). These brain regions are most commonly associated with synaptic dysfunction in SCZ, BD and MDD, as well as in putative alterations in synaptic protein levels upon psychotropic medication. SV2A is present at presynaptic terminals of both excitatory and inhibitory synapses throughout the brain, therefore in order to also capture all postsynaptic structures, we chose an antibody recognising all subtypes of Neuroligin (i.e. Neuroligin 1-4, NLGN), which are present at excitatory and inhibitory synapses ${ }^{36}$, rather than the commonly used postsynaptic density (PSD) marker PSD-95, which is primarily present at excitatory synapses ${ }^{37}$.

Both SV2A and NLGN immunostaining were present throughout grey but not white matter (Fig.1A). At higher magnification, we found that SV2A immunostaining displayed clear punctate structures with high contrast in the pyramidal cell layers. Presynaptic SV2A structures were most prominent at perisomatic regions, but absent from the nucleus and soma (Fig.1B,C). NLGN staining revealed smaller clusters that were also present in the soma, but not in the nucleus (Fig.1B,C). We determined the number of pre- and postsynaptic clusters individually, as well as their overlap as a measure of synaptic density. Furthermore, we determined the total area of clusters as a measure for total synaptic terminal area, and the intensity of staining within clusters as a relative measure of SV2A and NLGN protein levels (Fig.2). 
bioRxiv preprint doi: https://doi.org/10.1101/2020.04.14.033944 this version posted April 15, 2020. The copyright holder for this preprint (which was not certified by peer review) is the author/funder, who has granted bioRxiv a license to display the preprint in perpetuity. It is made available under aCC-BY-NC-ND 4.0 International license.

Analysis of SV2A cluster number showed a main effect of region, but no significant effects of treatment or region $\mathrm{x}$ treatment interaction. Likewise, there were no effects of treatment or region $\mathrm{x}$ treatment interaction for the total area of SV2A clusters or total intensity inside clusters (Fig.2A, Table 1). Thus, our data suggests that chronic exposure to either HAL or Li does not affect SV2A-containing presynaptic terminals, and, by inference, presynaptic terminals per se.

Analysis of NLGN cluster number showed a significant effect of both region and treatment, but no region $\mathrm{x}$ treatment interaction (Fig.2B, Table 1). Post-hoc analysis revealed that the treatment effect was driven by a significant increase in NLGN cluster number in both PFC and ACC upon exposure to Li as compared to VEHtreated animals. Total NLGN cluster area also showed a significant increase upon Li treatment (Fig.2B, Table 1), although for the ACC this did not survive correction for multiple comparisons (actual $\mathrm{p}=0.08$ ). There was no correlation between Li plasma level and NLGN cluster number or area (data not shown). Total NLGN staining intensity showed no significant effect of treatment (Fig.2B, Table 1). Thus, our data suggests that chronic $\mathrm{Li}$, but not HAL exposure, induces an increase in postsynaptic cluster number and size.

Finally, we analysed the number of overlapping SV2A/NLGN clusters, as these would be representative of functional synapses. There was an overall effect of region on overlapping cluster count (Fig.2C, Table 1), suggesting an overall difference in synaptic density between PFC and ACC, but there were no statistically significant effects of either treatment or a treatment $\mathrm{x}$ region interaction.

Table 1. Statistical analysis (2-way ANOVA) of SV2A and NLGN staining in rat frontal cortex upon HAL and Li treatment

\begin{tabular}{llll}
\hline Variable & Region & Treatment & Region x Treatment \\
\hline SV2A cluster count & $\mathrm{F}(1,28)=10.40 ; \mathbf{p}<\mathbf{0 . 0 1} ; \eta_{\mathrm{p}}{ }^{2}=0.27$ & $\mathrm{~F}(2,28)=2.072 ; \mathrm{ns}^{1}$ & $\mathrm{~F}(2,28)=2.442 ; \mathrm{ns}$ \\
SV2A cluster area & $\mathrm{F}(1,28)=7.570 ; \mathbf{p}<\mathbf{0 . 0 5} ; \eta_{\mathrm{p}}{ }^{2}=0.21$ & $\mathrm{~F}(2,28)=0.5517 ; \mathrm{ns}$ & $\mathrm{F}(2,28)=0.4628 ; \mathrm{ns}$ \\
SV2A staining intensity & $\mathrm{F}(1,28)=7.354 ; \mathbf{p}<\mathbf{0 . 0 5} ; \eta_{\mathrm{p}}{ }^{2}=0.21$ & $\mathrm{~F}(2,28)=0.2032 ; \mathrm{ns}$ & $\mathrm{F}(2,28)=0.0268 ; \mathrm{ns}$ \\
\hline NLGN cluster count & $\mathrm{F}(1,28)=4.376 ; \mathbf{p}<\mathbf{0 . 0 5} ; \eta_{\mathrm{p}}{ }^{2}=0.14$ & $\mathrm{~F}(2,28)=4.203 ; \mathbf{p}<\mathbf{0 . 0 5} ; \eta_{\mathrm{p}}{ }^{2}=0.64$ & $\mathrm{~F}(2,28)=0.1007 ; \mathrm{ns}$ \\
NLGN cluster area & $\mathrm{F}(1,28)=4.157 ; \mathrm{p}=0.051$ & $\mathrm{~F}(2,28)=3.580 ; \mathbf{p}<\mathbf{0 . 0 5} ; \eta_{\mathrm{p}}{ }^{2}=0.57$ & $\mathrm{~F}(2,28)=0.1245 ; \mathrm{ns}$ \\
NLGN staining intensity & $\mathrm{F}(1,28)=8.478 ; \mathbf{p}<\mathbf{0 . 0 1} ; \eta_{\mathrm{p}}{ }^{2}=0.23$ & $\mathrm{~F}(2,28)=1.986 ; \mathrm{ns}$ & $\mathrm{F}(2,28)=0.5509 ; \mathrm{ns}$ \\
\hline Synaptic cluster count & $\mathrm{F}(1,28)=5.506 ; \mathbf{p}<\mathbf{0 . 0 5} ; \eta_{\mathrm{p}}{ }^{2}=0.16$ & $\mathrm{~F}(2,28)=2.026 ; \mathrm{ns}$ & $\mathrm{F}(2,28)=0.1408 ; \mathrm{ns}$ \\
\hline
\end{tabular}

${ }^{1}$ ns, not significant

\section{Effect of Olanzapine treatment on synaptic markers}

To test whether the results obtained with HAL exposure generalises to other antipsychotics, we analysed synaptic clusters in a separate cohort of animals treated for 28 days with vehicle or $7.5 \mathrm{mg} / \mathrm{kg} /$ day Olanzapine (OLZ; Supplementary Figure S2A,B). Blood plasma levels of OLZ fell within the clinically relevant range. 
bioRxiv preprint doi: https://doi org/10.1101/2020.04.14.033944; this version posted April 15,2020 . The copyright holder for this preprint (which was not certified by peer review) is the author/funder, who has granted bioRxiv a license to display the preprint in perpetuity. It is made available under aCC-BY-NC-ND 4.0 International license.

We found no effect of OLZ treatment on SV2A or NLGN cluster number, or overlapping synapse count (Supplementary Figure S2C, Table 2). Likewise, we found no effect on cluster area or staining intensity of either marker (Supplementary Figure S2D-E, Table 2). Thus, we show that OLZ, like HAL, does not affect pre- or postsynaptic clusters.

Table 2. Statistical analysis (2-way ANOVA) of SV2A and NLGN staining in rat frontal cortex upon OLZ treatment

\begin{tabular}{llll}
\hline Variable & Region & Treatment & Region x Treatment \\
\hline SV2A cluster count & $\mathrm{F}(1,14)=1.480 ; \mathrm{ns}^{1}$ & $\mathrm{~F}(1,14)=0.1845 ; \mathrm{ns}$ & $\mathrm{F}(1,14)=0.4974 ; \mathrm{ns}$ \\
SV2A cluster area & $\mathrm{F}(1,14)=0.0268 ; \mathrm{ns}$ & $\mathrm{F}(1,14)=1.222 ; \mathrm{ns}$ & $\mathrm{F}(1,14)=0.0013 ; \mathrm{ns}$ \\
SV2A staining intensity & $\mathrm{F}(1,14)=0.148 ; \mathrm{ns}$ & $\mathrm{F}(1,14)=1.518 ; \mathrm{ns}$ & $\mathrm{F}(1,14)=0.1523 ; \mathrm{ns}$ \\
\hline NLGN cluster count & $\mathrm{F}(1,14)=0.0605 ; \mathrm{ns}$ & $\mathrm{F}(1,14)=0.7205 ; \mathrm{ns}$ & $\mathrm{F}(1,14)=0.5051 ; \mathrm{ns}$ \\
NLGN cluster area & $\mathrm{F}(1,14)=0.0063 ; \mathrm{ns}$ & $\mathrm{F}(1,14)=0.9316 ; \mathrm{ns}$ & $\mathrm{F}(1,14)=0.9005 ; \mathrm{ns}$ \\
NLGN staining intensity & $\mathrm{F}(1,14)=0.1431 ; \mathrm{ns}$ & $\mathrm{F}(1,14)=0.9287 ; \mathrm{ns}$ & $\mathrm{F}(1,14)=2.076 ; \mathrm{ns}$ \\
\hline Synaptic cluster count & $\mathrm{F}(1,14)=0.235 ; \mathrm{ns}$ & $\mathrm{F}(1,14)=0.8453 ; \mathrm{ns}$ & $\mathrm{F}(1,14)=0.1283 ; \mathrm{ns}$ \\
\hline
\end{tabular}

${ }^{1}$ ns, not significant 


\section{Discussion}

\section{Summary and interpretation of results}

Our study presented here investigates the effect of chronic exposure (28d) to the typical antipsychotic Haloperidol (HAL), the atypical antipsychotic Olanzapine (OLZ), and the mood stabiliser lithium (Li) on preand postsynaptic clusters using SV2A and NLGN as respective markers. In agreement with our hypothesis, we find that neither OLZ or HAL alter SV2A or NLGN synaptic cluster density, cluster area, or immunostaining intensity. These data confirm our recently published observations that neither HAL nor OLZ had any effect on either overall SV2A protein levels or $\left[{ }^{3} \mathrm{H}\right]-\mathrm{UCB}-\mathrm{J}$ specific binding in the rat PFC and $\mathrm{ACC}^{19}$. Our new data extends this prior work by demonstrating at higher resolution that, under the conditions tested, these APD also have no effect on synaptic clusters. Furthermore, we provide evidence for a contrasting effect of chronic Li exposure, which selectively enhances postsynaptic cluster count and area in both the PFC and ACC, without affecting SV2A-containing presynaptic terminal density or overall synapse count. The implications of these observations for clinical studies will be discussed further on.

This study is, to our knowledge, the first to investigate the effect of these psychotropic medications on SV2A clusters. Previous studies in rats have however investigated the impact of chronic exposure to APD on protein levels of Synaptophysin (SYN), a presynaptic vesicle protein that shows high correlation with SV2A distribution ${ }^{12}$. The majority of these studies found no statistically significant effects of either HAL or OLZ on SYN protein levels in the rat hippocampus and frontal cortex ${ }^{23,38-40}$; one study reported increased SYN levels in cortical lysates upon chronic administration of OLZ, however this study did not use clinically comparable dosing $^{41}$. Supporting the majority of the rat studies, exposure of rhesus monkeys to clinically-comparable levels of HAL for $>1$ year found no change in SYN, either at DNA or protein levels, in cortical areas relevant to schizophrenia ${ }^{42,43}$. The effect of APD on postsynaptic marker expression has mostly been investigated at the mRNA level, with Homerla and PSD-95 as the most commonly reported markers. For Homer1a mRNA levels in the cortex upon HAL and OLZ administration results are inconsistent, with some studies reporting upregulation and others downregulation ${ }^{44-47}$. These findings have yet to be confirmed at the protein level. For PSD-95 mRNA levels in the cortex findings were likewise inconsistent ${ }^{45,47}$, however no change was found for PSD-95 at the protein level in either striatum or frontal cortex ${ }^{39,48}$. Notably, both Homerla and PSD-95 are primarily located at excitatory synapses therefore these results may not be reflective of overall synaptic protein levels.

Studies on the effects of chronic Li exposure on SYN reported no effect on either protein $^{40,41}$ or mRNA levels ${ }^{49}$. On the other hand, Li exposure was shown to increase mRNA levels of Synapsins, a class of proteins that like SV2A and SYN is located on presynaptic vesicles and is involved in neurotransmitter release ${ }^{22}$, and is reduced in $\mathrm{BD}^{40}$. The latter study, however, did not see an effect of $\mathrm{Li}$ on Synapsin protein levels in the hippocampus. In cell culture, Li induced enhanced recruitment of both SYN and PSD95 to synapses ${ }^{50}$, indicative of a synaptogenic effect. Indeed, multiple studies confirm that Li treatment enhances dendritic 
bioRxiv preprint doi: https://doi.org/10.1101/2020.04.14.033944; this version posted April 15, 2020. The copyright holder for this preprint (which was not certified by peer review) is the author/funder, who has granted bioRxiv a license to display the preprint in perpetuity. It is made available under aCC-BY-NC-ND 4.0 International license.

branching and synapse formation, both in vitro and in vivo ${ }^{21,51}$. Thus, the neurotropic effect of Li may underlie the increase in postsynaptic clusters observed in our study.

Collectively, our data are consistent with these previous observations. Specifically, our results for SV2A parallel earlier studies on the effect of APDs and Li on SYN, whereas the effect of Li on increased NLGN clusters reflects the oft-reported neurotropic effect of Li. It should be taken into account however that direct comparisons are difficult to make as the literature is heterogeneous in terms of measures reported (protein $v s$ mRNA), synaptic markers studied, regimens used to establish chronic exposure (daily injections, administration via food intake, or constant exposure via mini-pumps), length of exposure, as well as concentrations of drugs administered. Furthermore, due to slightly lower blood levels of Li in our samples, which fell just below the therapeutic range and earlier observed plasma levels ${ }^{26}$ the effect of Li treatment may not have been as robust in our study compared to other investigations, and the effect on overlapping synaptic cluster count upon Li exposure may be underestimated.

\section{Limitations}

Limitations of our study should be noted. First, drug treatment was performed in otherwise healthy animals, therefore the interaction between drug exposure and illness was not assessed. Interestingly, OLZ partially rescued stress-induced reduction of SYN and PSD-95 protein levels in the rat prefrontal cortex ${ }^{39}$, as well as PCP-induced reduction of SYN and PSD-95 protein levels and neurite outgrowth in neuronal culture ${ }^{52}$, and PCP-induced reduction in spine density ${ }^{53}$, without affecting these measures in control condition. Future research should therefore include investigating the effect of APD and mood stabilising drugs on SV2A protein levels and synaptic cluster density in animal models relevant for the study of SCZ and mood disorder.

Second, the number of synapses detected is highly dependent on the synaptic marker, method of detection, and method of quantification used. It is not uncommon to see different numbers for pre- and postsynaptic markers, which will also be reflected by a lower number of overlapping (total) synapses as compared to the individual markers ${ }^{54}$ (Fig.2 and S2). Notably, our reported density of 0.1-0.2 SV2A clusters per $\mu \mathrm{m}^{3}$ is in the same order of magnitude as observations by Rasakham et al. ${ }^{55}$, who reported an approximate synaptic cluster density of 0.5 clusters per $\mu \mathrm{m}^{3}$ in the PFC of rats in a similar age range, using Synaptophysin and PSD95 immunostaining with fluorescence microscopy. At higher resolution, an electron microscopy study detected up to 6 synaptic clusters per $\mu \mathrm{m}^{3}$ in the rat $\mathrm{PFC}^{56}$, suggesting only a subset of synaptic clusters will be detected at the resolution of fluorescence microscopy. Thus, our study should be considered to reflect a percentage of change rather than a change in absolute cluster numbers.

Third, on the basis of our study we cannot exclude that APD exposure causes more subtle effects in synapse rearrangement that cannot be detected at the resolution of light microscopy. Electron microscopy studies in the rat PFC after up to 1 year of exposure to HAL showed a shift towards an increased number of inhibitory synapses without affecting total synapse number or synaptic vesicle density ${ }^{57,58}$. Furthermore, autoradiography studies from our lab revealed increased $\mathrm{GABA}_{\mathrm{A}}$ receptor binding in the rat $\mathrm{ACC}$ upon chronic 
HAL exposure ${ }^{59}$. Future studies combining SV2A staining with specific pre- and postsynaptic markers for inhibitory and excitatory synapses, such as vGAT/Gephyrin or vGlut/PSD95, respectively, may give more insight into the involvement of SV2A in regulating the excitatory/inhibitory balance (E/I balance) during disease progression and upon drug exposure.

In this context it is interesting to note that SV2A was found to be differentially associated with GABAergic and glutamatergic synapses depending on brain region and developmental stage ${ }^{60,61}$, and that an $\mathrm{E} / \mathrm{I}$ imbalance has been associated with both $\mathrm{SCZ}$ and $\mathrm{BD}^{62,63}$. It therefore remains to be investigated whether a reduction of SV2A in psychiatric disorders truly represents a loss of synapses, or rather a disturbance in the $\mathrm{E} / \mathrm{I}$ balance. Elucidating the functional impact of reduced SV2A levels on neurotransmitter release and synaptic signalling also remains a priority for future work.

\section{Implications for human studies}

Our findings may have broader implications for clinical research into synaptic dysfunction in psychiatric disorder using both neuroimaging and post-mortem methods. SV2A is a synaptic protein of great interest due to the development of the UCB-J tracers, which have enabled in vivo imaging of presynaptic terminals in the living human brain ${ }^{12,13,19}$. One potential confounding factor in such human PET studies is whether psychotropic medication has an impact on the specific binding of the SV2A radioligand. To date, little is known about the effect of psychotropic mediation on SV2A, and post-mortem studies in experimental animals are thus essential for the correct interpretation of clinical PET studies ${ }^{35}$. Our data presented here provide evidence that APDs are unlikely to account for the reduced SV2A binding in SCZ patients as observed by PET ${ }^{19}$. More broadly, the lack of change in either SV2A, NLGN or synaptic (overlapping SV2A/NLGN) cluster density suggests APD treatment may be unrelated to changes in other synaptic markers found in human post mortem SCZ tissue, such as reduced SYN levels ${ }^{8,64}$. Whether SV2A protein levels are reduced in BD and SCZ post-mortem brain tissue has yet to be investigated, but could be expected to reflect the same changes as those observed with SYN.

The increase in NLGN cluster count and area upon Li treatment is consistent with the reported neurotrophic effects of this drug, although the mechanisms underlying this effect are as yet poorly understood $^{27}$. At the resolution of our data we are unable to say whether the increase in NLGN clusters is due to an increase in the number of postsynaptic specialisations (such as increased spine density), or whether an increase in the size of pre-existing clusters due to postsynaptic protein accumulation ${ }^{24}$ leads to inclusion of clusters that were previously below detection level. It is interesting to note that we found a significant increase in NLGN clusters upon lithium treatment despite plasma levels falling just below the clinically relevant therapeutic range. It is tempting to speculate that the synaptogenic effects of $\mathrm{Li}$ do not underlie the improvement in the core $\mathrm{BD}$ symptoms of mania and depression, which are the main clinical measures to assess treatment efficacy in $\mathrm{BD}$, but rather contribute to some therapeutic benefit of Li that is less well 
established such as reducing cognitive decline ${ }^{65}$. However, more work is needed to understand the exact implications of these results for the effect of treatment in BD.

In summary, our study shows that chronic APD exposure (up to 28 days) does not alter pre- or postsynaptic cluster density. In contrast, chronic Li exposure (up to 28 days) enhances postsynaptic clusters, although we saw no effect on the presynapse. Our data provide clarity with regard to the impact of psychotropic treatment on SV2A and synaptic density, which will aid in the interpretation of clinical studies. In particular, our findings reinforce the suggestion that reduced SV2A in SCZ represents a pathology intrinsic to the illness and not an adaptation to antipsychotic drug exposure ${ }^{19}$. Further work is however needed to understand how the apparent effects of $\mathrm{Li}$ on the post-synapse are related to its beneficial clinical effects on mood and cognition.

Acknowledgements: We would like to thank George Chennell and Chen Liang of the Wohl Cellular Imaging Centre (King's College London) for their valuable help with image acquiry.

ACV acknowledges financial support for this study from the Medical Research Council (New Investigator Research Grant (NIRG), MR/N025377/1). The work (at King's College, London) was also supported by the Medical Research Council (MRC) Centre grant (MR/N026063/1). These funding sources had no further role in study design; in the collection, analysis and interpretation of the data; in the writing of the report; and in the decision to submit the paper for publication.

Conflict of Interest: The authors declare no conflict of interest. 
bioRxiv preprint doi: https://doi.org/10.1101/2020.04.14.033944; this version posted April 15, 2020. The copyright holder for this preprint (which was not certified by peer review) is the author/funder, who has granted bioRxiv a license to display the preprint in perpetuity. It is made available under aCC-BY-NC-ND 4.0 International license.

Main figures and legends

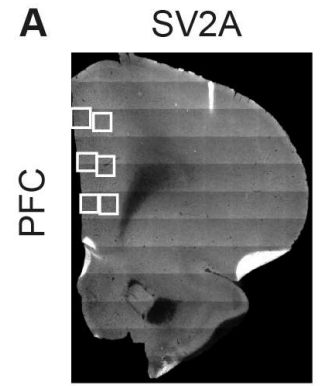

NLGN
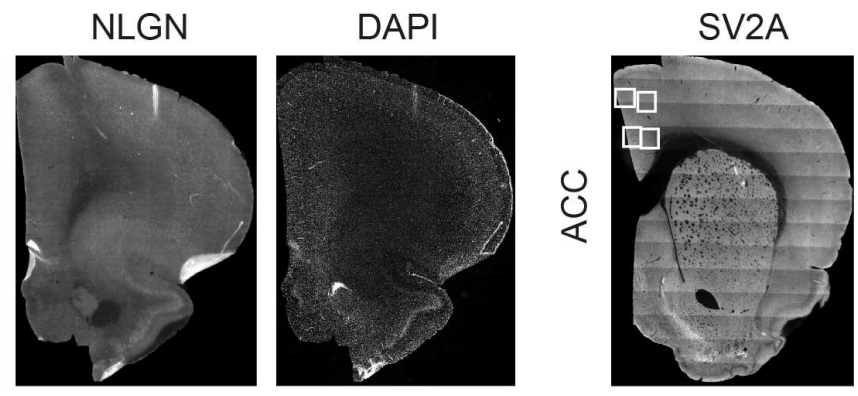

NLGN
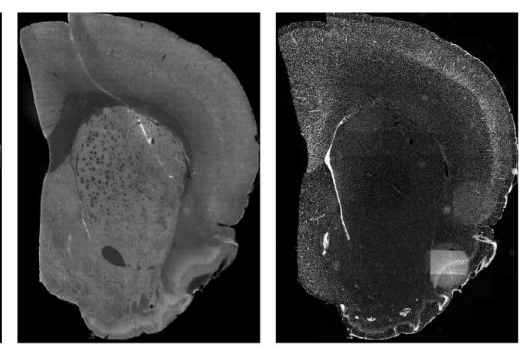

B

VEH

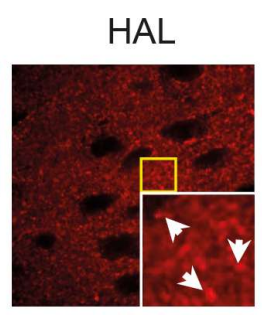

$\mathrm{Li}$

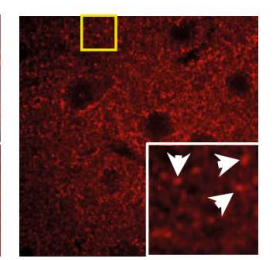

C

VEH

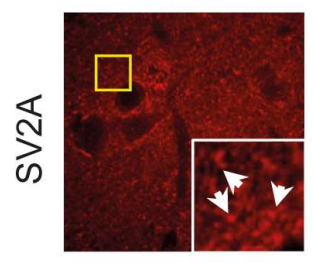

HAL

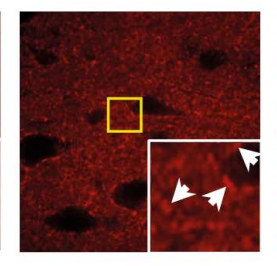

$\mathrm{Li}$
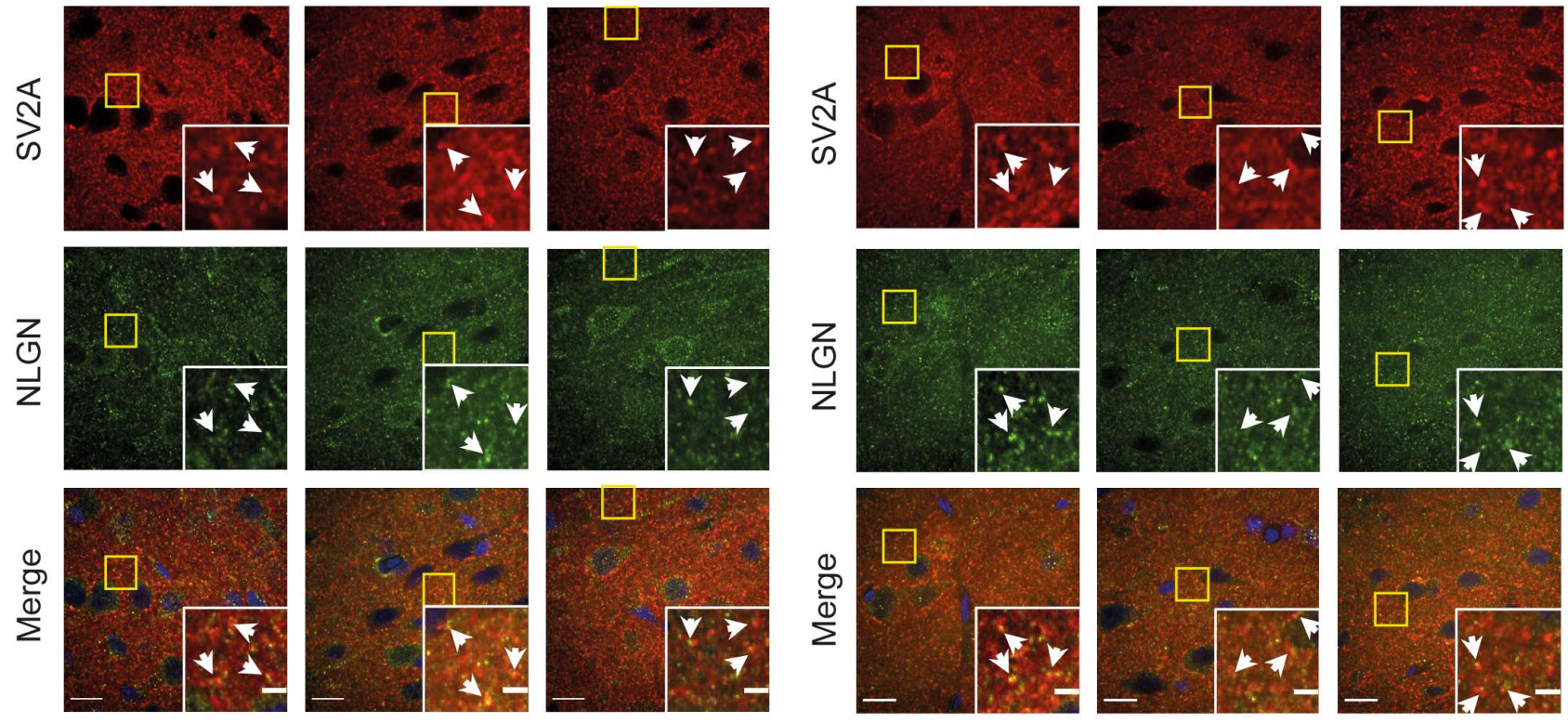

Figure 1. Confocal images of synaptic staining in rat $\mathrm{PFC}$ and $\mathrm{ACC}$ upon 28 days exposure to Haloperidol or Lithium. A. Fluorescent image (automatically stitched) of rat PFC (left) and ACC (right), stained with SV2A, NLGN, or DAPI as indicated. White squares indicate the positions where higher resolution confocal images (panel B,C) were acquired. B,C. Confocal images of the PFC (B) or ACC (C) showing synaptic staining with SV2A (top, red), NLGN (middle, green) or merged including DAPI (blue, bottom). Treatments are indicated at the top (VEH, Vehicle; HAL, $0.5 \mathrm{mg} / \mathrm{kg}$ /day Haloperidol; Li, $2 \mathrm{mM}$ eq/kg/day Lithium). Yellow boxes indicate the position of the zoomed insets. Arrows indicate examples of colocalisation. Scalebar $15 \mu \mathrm{m}$ (entire image) or $4 \mu \mathrm{m}$ (zoomed insets). 
A • VEH $\quad \mathrm{HAL} \triangle \mathrm{Li}$
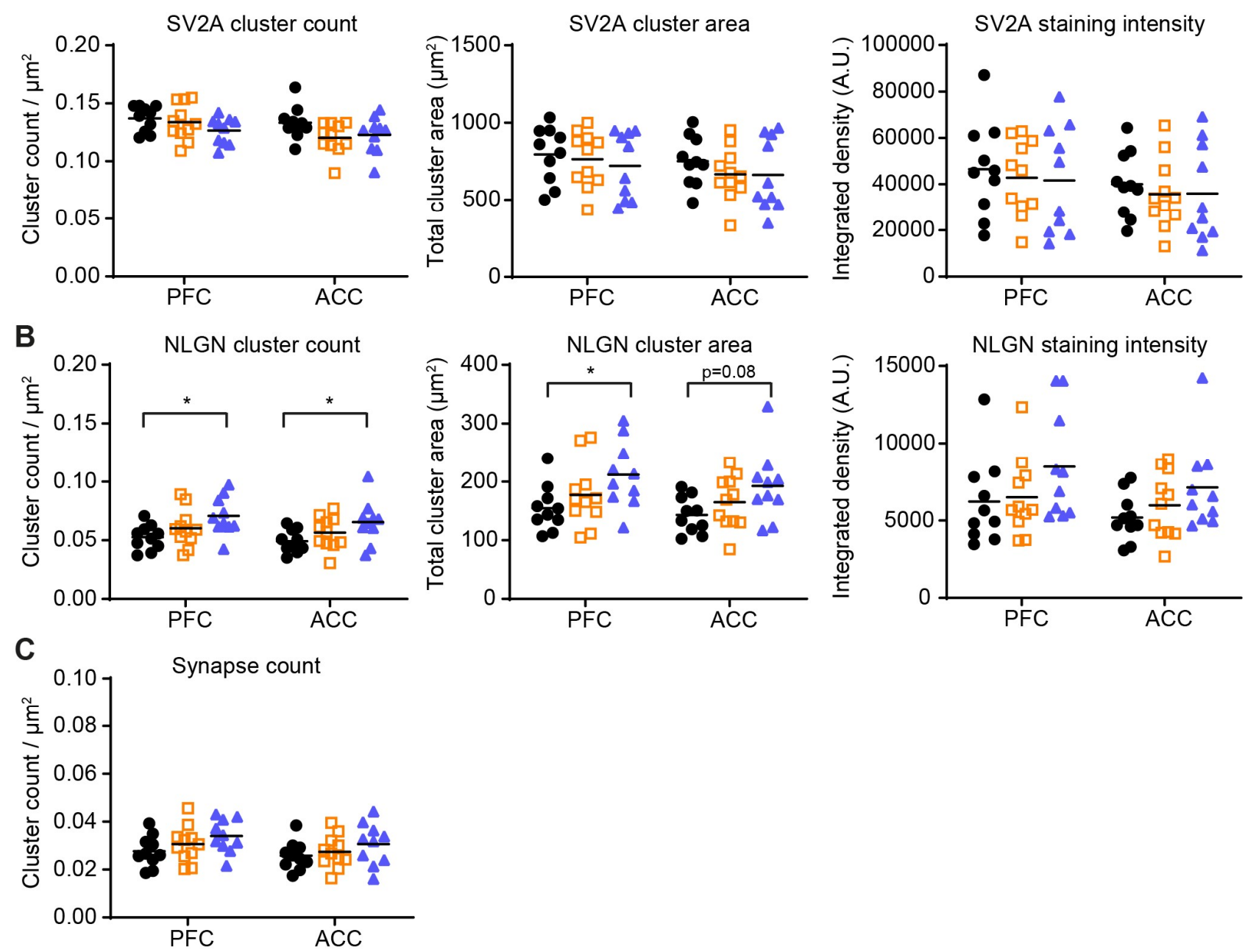

Figure 2. Quantification of SV2A and NLGN clusters upon 28 days exposure to Haloperidol or Lithium.

A-B. Scatter plots of cluster count (left), cluster area (middle) and staining intensity (right) for rat PFC and ACC based on staining for SV2A (A), or NLGN (B). Treatments are indicated at the top (VEH, Vehicle, black circles; HAL, $0.5 \mathrm{mg} / \mathrm{kg} /$ day Haloperidol, orange squares; Li, $2 \mathrm{mM} \mathrm{eq} / \mathrm{kg} /$ day Lithium, blue triangles). C. Scatter plot of cluster count of overlapping SV2A/NLGN clusters.

Average value represents mean; two-way ANOVA with Bonferroni’s correction; * $\mathrm{p}<0.05$. 
bioRxiv preprint doi: https://doi.org/10.1101/2020.04.14.033944; this version posted April 15, 2020. The copyright holder for this preprint (which was not certified by peer review) is the author/funder, who has granted bioRxiv a license to display the preprint in perpetuity. It is made available under aCC-BY-NC-ND 4.0 International license.

\section{References}

1 Glausier JR, Lewis DA. Dendritic spine pathology in schizophrenia. Neuroscience 2013; 251: 90-107.

2 MacDonald ML, Alhassan J, Newman JT, Richard M, Gu H, Kelly RM et al. Selective loss of smaller spines in schizophrenia. Am J Psychiatry 2017; 174: 586-594.

3 Duman RS, Sanacora G, Krystal JH. Altered connectivity in depression: GABA and glutamate neurotransmitter deficits and reversal by novel treatments. Neuron 2019; 102: 75-90.

4 Savitz J, Drevets WC. Bipolar and major depressive disorder: neuroimaging the developmental-degenerative divide. Neurosci Biobehav Rev 2009; 33: 699-771.

5 Fromer M, Pocklington AJ, Kavanagh DH, Williams HJ, Dwyer S, Gormley P et al. De novo mutations in schizophrenia implicate synaptic networks. Nature 2014; 506: 179-184.

6 Kang HJ, Voleti B, Hajszan T, Rajkowska G, Stockmeier CA, Licznerski P et al. Decreased expression of synapse-related genes and loss of synapses in major depressive disorder. Nat Med 2012; 18: 1413-1417.

7 Duric V, Banasr M, Stockmeier CA, Simen AA, Newton SS, Overholser JC et al. Altered expression of synapse and glutamate related genes in post-mortem hippocampus of depressed subjects. Int J Neuropsychopharmacol 2013; 16: 69-82.

8 Osimo EF, Beck K, Reis Marques T, Howes OD. Synaptic loss in schizophrenia: a meta-analysis and systematic review of synaptic protein and mRNA measures. Mol Psychiatry 2019; 24: 549-561.

9 Kim H-W, Rapoport SI, Rao JS. Altered expression of apoptotic factors and synaptic markers in postmortem brain from bipolar disorder patients. Neurobiol Dis 2010; 37: 596-603.

10 Eastwood SL, Harrison PJ. Synaptic pathology in the anterior cingulate cortex in schizophrenia and mood disorders. A review and a Western blot study of synaptophysin, GAP-43 and the complexins. Brain Res Bull 2001; 55: 569-578.

11 Berdenis van Berlekom A, Muflihah CH, Snijders GJLJ, MacGillavry HD, Middeldorp J, Hol EM et al. Synapse Pathology in Schizophrenia: A Meta-analysis of Postsynaptic Elements in Postmortem Brain Studies. Schizophr Bull 2020; 46: 374-386.

12 Finnema SJ, Nabulsi NB, Eid T, Detyniecki K, Lin S-F, Chen M-K et al. Imaging synaptic density in the living human brain. Sci Transl Med 2016; 8: 348 ra96.

13 Cai Z, Li S, Matuskey D, Nabulsi N, Huang Y. PET imaging of synaptic density: A new tool for investigation of neuropsychiatric diseases. Neurosci Lett 2019; 691: 44-50.

14 McCluskey SP, Plisson C, Rabiner EA, Howes O. Advances in CNS PET: the state-of-the-art for new imaging targets for pathophysiology and drug development. Eur J Nucl Med Mol Imaging 2019. doi:10.1007/s00259-01904488-0.

15 Nowack A, Yao J, Custer KL, Bajjalieh SM. SV2 regulates neurotransmitter release via multiple mechanisms. Am J Physiol Cell Physiol 2010; 299: C960-7.

16 Stout K, Dunn A, Hoffman C, Miller GW. The synaptic vesicle glycoprotein 2: structure, function, and disease relevance. ACS Chem Neurosci 2019. doi:10.1021/acschemneuro.9b00351.

17 Bartholome O, Van den Ackerveken P, Sánchez Gil J, de la Brassinne Bonardeaux O, Leprince P, Franzen R et al. Puzzling out synaptic vesicle 2 family members functions. Front Mol Neurosci 2017; 10: 148.

18 Mendoza-Torreblanca JG, Vanoye-Carlo A, Phillips-Farfán BV, Carmona-Aparicio L, Gómez-Lira G. Synaptic vesicle protein 2A: basic facts and role in synaptic function. Eur J Neurosci 2013; 38: 3529-3539.

19 Onwordi EC, Halff EF, Whitehurst T, Mansur A, Cotel M-C, Wells L et al. Synaptic density marker SV2A is reduced in schizophrenia patients and unaffected by antipsychotics in rats. Nat Commun 2020; 11: 246.

20 Kelley JJ, Gao XM, Tamminga CA, Roberts RC. The effect of chronic haloperidol treatment on dendritic spines in the rat striatum. Exp Neurol 1997; 146: 471-478. 
bioRxiv preprint doi: https://doi.org/10.1101/2020.04.14.033944; this version posted April 15, 2020. The copyright holder for this preprint (which was not certified by peer review) is the author/funder, who has granted bioRxiv a license to display the preprint in perpetuity. It is made available under aCC-BY-NC-ND 4.0 International license.

21 Shim SS, Hammonds MD, Mervis RF. Four weeks lithium treatment alters neuronal dendrites in the rat hippocampus. Int J Neuropsychopharmacol 2013; 16: 1373-1382.

22 Joshi H, Sharma R, Prashar S, Ho J, Thomson S, Mishra R. Differential Expression of Synapsin I and II upon Treatment by Lithium and Valproic Acid in Various Brain Regions. Int J Neuropsychopharmacol 2018; 21: 616622.

23 Barr AM, Young CE, Phillips AG, Honer WG. Selective effects of typical antipsychotic drugs on SNAP-25 and synaptophysin in the hippocampal trisynaptic pathway. Int J Neuropsychopharmacol 2006; 9: 457-463.

24 Nanavati D, Austin DR, Catapano LA, Luckenbaugh DA, Dosemeci A, Manji HK et al. The effects of chronic treatment with mood stabilizers on the rat hippocampal post-synaptic density proteome. J Neurochem 2011; 119: $617-629$.

25 Vernon AC, Natesan S, Modo M, Kapur S. Effect of chronic antipsychotic treatment on brain structure: a serial magnetic resonance imaging study with ex vivo and postmortem confirmation. Biol Psychiatry 2011; 69: 936944.

26 Vernon AC, Natesan S, Crum WR, Cooper JD, Modo M, Williams SCR et al. Contrasting effects of haloperidol and lithium on rodent brain structure: a magnetic resonance imaging study with postmortem confirmation. Biol Psychiatry 2012; 71: 855-863.

27 Won E, Kim Y-K. An Oldie but Goodie: Lithium in the Treatment of Bipolar Disorder through Neuroprotective and Neurotrophic Mechanisms. Int J Mol Sci 2017; 18. doi:10.3390/ijms18122679.

Quinn R. Comparing rat's to human's age: how old is my rat in people years? Nutrition 2005; 21: $775-777$.

29 Kapur S, VanderSpek SC, Brownlee BA, Nobrega JN. Antipsychotic dosing in preclinical models is often unrepresentative of the clinical condition: a suggested solution based on in vivo occupancy. J Pharmacol Exp Ther 2003; 305: 625-631.

30 Turrone P, Remington G, Kapur S, Nobrega JN. Continuous but not intermittent olanzapine infusion induces vacuous chewing movements in rats. Biol Psychiatry 2005; 57: 406-411.

31 Turrone P, Remington G, Kapur S, Nobrega JN. The relationship between dopamine D2 receptor occupancy and the vacuous chewing movement syndrome in rats. Psychopharmacology 2003; 165: 166-171.

32 McQuade R, Leitch MM, Gartside SE, Young AH. Effect of chronic lithium treatment on glucocorticoid and 5HT1A receptor messenger RNA in hippocampal and dorsal raphe nucleus regions of the rat brain. $J$ Psychopharmacol (Oxford) 2004; 18: 496-501.

33 Notter T, Panzanelli P, Pfister S, Mircsof D, Fritschy J-M. A protocol for concurrent high-quality immunohistochemical and biochemical analyses in adult mouse central nervous system. Eur J Neurosci 2014; 39: 165-175.

34 Schneider Gasser EM, Straub CJ, Panzanelli P, Weinmann O, Sassoè-Pognetto M, Fritschy J-M. Immunofluorescence in brain sections: simultaneous detection of presynaptic and postsynaptic proteins in identified neurons. Nat Protoc 2006; 1: 1887-1897.

35 Notter T, Coughlin JM, Gschwind T, Weber-Stadlbauer U, Wang Y, Kassiou M et al. Translational evaluation of translocator protein as a marker of neuroinflammation in schizophrenia. Mol Psychiatry 2018; 23: 323-334.

36 Bemben MA, Shipman SL, Nicoll RA, Roche KW. The cellular and molecular landscape of neuroligins. Trends Neurosci 2015; 38: 496-505.

37 El-Husseini AE, Schnell E, Chetkovich DM, Nicoll RA, Bredt DS. PSD-95 involvement in maturation of excitatory synapses. Science 2000; 290: 1364-1368.

38 Ozdemir H, Ertugrul A, Basar K, Saka E. Differential effects of antipsychotics on hippocampal presynaptic protein expressions and recognition memory in a schizophrenia model in mice. Prog Neuropsychopharmacol Biol Psychiatry 2012; 39: 62-68.

39 Seo MK, Lee CH, Cho HY, You YS, Lee BJ, Lee JG et al. Effects of antipsychotic drugs on the expression of synapse-associated proteins in the frontal cortex of rats subjected to immobilization stress. Psychiatry Res 2015; 229: 968-974. 
bioRxiv preprint doi: https://doi.org/10.1101/2020.04.14.033944; this version posted April 15, 2020. The copyright holder for this preprint (which was not certified by peer review) is the author/funder, who has granted bioRxiv a license to display the preprint in perpetuity. It is made available under aCC-BY-NC-ND 4.0 International license.

40 Vawter MP, Thatcher L, Usen N, Hyde TM, Kleinman JE, Freed WJ. Reduction of synapsin in the hippocampus of patients with bipolar disorder and schizophrenia. Mol Psychiatry 2002; 7: 571-578.

41 Scarr E, Dean B. Altered neuronal markers following treatment with mood stabilizer and antipsychotic drugs indicate an increased likelihood of neurotransmitter release. Clin Psychopharmacol Neurosci 2012; 10: $25-33$.

42 Lidow MS, Song ZM, Castner SA, Allen PB, Greengard P, Goldman-Rakic PS. Antipsychotic treatment induces alterations in dendrite- and spine-associated proteins in dopamine-rich areas of the primate cerebral cortex. Biol Psychiatry 2001; 49: 1-12.

43 MacDonald ML, Garver M, Newman J, Sun Z, Kannarkat J, Salisbury R et al. Synaptic proteome alterations in the primary auditory cortex of individuals with schizophrenia. JAMA Psychiatry 2019; : 1-10.

44 Iasevoli F, Tomasetti C, Marmo F, Bravi D, Arnt J, de Bartolomeis A. Divergent acute and chronic modulation of glutamatergic postsynaptic density genes expression by the antipsychotics haloperidol and sertindole. Psychopharmacology 2010; 212: 329-344.

45 Iasevoli F, Ambesi-Impiombato A, Fiore G, Panariello F, Muscettola G, de Bartolomeis A. Pattern of acute induction of Homerla gene is preserved after chronic treatment with first- and second-generation antipsychotics: effect of short-term drug discontinuation and comparison with Homer1a-interacting genes. J Psychopharmacol (Oxford) 2011; 25: 875-887.

46 Tomasetti C, Dell'Aversano C, Iasevoli F, Marmo F, de Bartolomeis A. The acute and chronic effects of combined antipsychotic-mood stabilizing treatment on the expression of cortical and striatal postsynaptic density genes. Prog Neuropsychopharmacol Biol Psychiatry 2011; 35: 184-197.

47 Buonaguro EF, Iasevoli F, Marmo F, Eramo A, Latte G, Avagliano C et al. Re-arrangements of gene transcripts at glutamatergic synapses after prolonged treatments with antipsychotics: A putative link with synaptic remodeling. Prog Neuropsychopharmacol Biol Psychiatry 2017; 76: 29-41.

48 Gardoni F, Frasca A, Zianni E, Riva MA, Di Luca M, Fumagalli F. Repeated treatment with haloperidol, but not olanzapine, alters synaptic NMDA receptor composition in rat striatum. Eur Neuropsychopharmacol 2008; 18: 531-534.

49 Zucker M, Weizman A, Harel D, Rehavi M. Changes in vesicular monoamine transporter (VMAT2) and synaptophysin in rat Substantia nigra and prefrontal cortex induced by psychotropic drugs. Neuropsychobiology 2001; 44: 187-191.

50 Kim HJ, Thayer SA. Lithium increases synapse formation between hippocampal neurons by depleting phosphoinositides. Mol Pharmacol 2009; 75: 1021-1030.

51 Park SW, Lee JG, Seo MK, Cho HY, Lee CH, Lee JH et al. Effects of mood-stabilizing drugs on dendritic outgrowth and synaptic protein levels in primary hippocampal neurons. Bipolar Disord 2015; 17: 278-290.

52 Zhang Q, Yu Y, Huang X-F. Olanzapine Prevents the PCP-induced Reduction in the Neurite Outgrowth of Prefrontal Cortical Neurons via NRG1. Sci Rep 2016; 6: 19581.

53 Elsworth JD, Morrow BA, Hajszan T, Leranth C, Roth RH. Phencyclidine-induced loss of asymmetric spine synapses in rodent prefrontal cortex is reversed by acute and chronic treatment with olanzapine. Neuropsychopharmacology 2011; 36: 2054-2061.

54 Gottschling C, Geissler M, Springer G, Wolf R, Juckel G, Faissner A. First and second generation antipsychotics differentially affect structural and functional properties of rat hippocampal neuron synapses. Neuroscience 2016; 337: $117-130$.

55 Rasakham K, Schmidt HD, Kay K, Huizenga MN, Calcagno N, Pierce RC et al. Synapse density and dendritic complexity are reduced in the prefrontal cortex following seven days of forced abstinence from cocaine selfadministration. PLoS One 2014; 9: e102524.

56 Csabai D, Wiborg O, Czéh B. Reduced synapse and axon numbers in the prefrontal cortex of rats subjected to a chronic stress model for depression. Front Cell Neurosci 2018; 12: 24. 
bioRxiv preprint doi: https://doi.org/10.1101/2020.04.14.033944 this version posted April 15, 2020. The copyright holder for this preprint (which was not certified by peer review) is the author/funder, who has granted bioRxiv a license to display the preprint in perpetuity. It is made available under aCC-BY-NC-ND 4.0 International license.

57 Vincent SL, McSparren J, Wang RY, Benes FM. Evidence for ultrastructural changes in cortical axodendritic synapses following long-term treatment with haloperidol or clozapine. Neuropsychopharmacology 1991; 5: 147 155.

58 Benes FM, Paskevich PA, Davidson J, Domesick VB. Synaptic rearrangements in medial prefrontal cortex of haloperidol-treated rats. Brain Res 1985; 348: 15-20.

59 Peris-Yague A, Kiemes A, Cash D, Cotel M-C, Singh N, Vernon AC et al. Region-specific and dose-specific effects of chronic haloperidol exposure on $\left[{ }^{3} \mathrm{H}\right]$ Flumazenil and $\left[{ }^{3} \mathrm{H}\right]$ Ro15-4513 $\mathrm{GABA}_{\mathrm{A}}$ receptor binding sites in the rat brain. BioRxiv 2019. doi:10.1101/869941.

60 Vanoye-Carlo A, Gómez-Lira G. Differential expression of SV2A in hippocampal glutamatergic and GABAergic terminals during postnatal development. Brain Res 2019; 1715: 73-83.

61 Mendoza-Torreblanca JG, García-Cruz ME, Sánchez-Cruz I, Gomez-Gonzalez B, Juárez-Méndez S, Gómez-Lira G. Analysis of differential expression of synaptic vesicle protein 2A in the adult rat brain. Neuroscience 2019 . doi:10.1016/j.neuroscience.2019.09.004.

62 Howes O, McCutcheon R, Stone J. Glutamate and dopamine in schizophrenia: an update for the 21 st century. $J$ Psychopharmacol (Oxford) 2015; 29: 97-115.

63 Mertens J, Wang Q-W, Kim Y, Yu DX, Pham S, Yang B et al. Differential responses to lithium in hyperexcitable neurons from patients with bipolar disorder. Nature 2015; 527: 95-99.

64 Egbujo CN, Sinclair D, Hahn C-G. Dysregulations of synaptic vesicle trafficking in schizophrenia. Curr Psychiatry Rep 2016; 18: 77.

65 Wang Y, An X, Zhang X, Liu J, Wang J, Yang Z. Lithium chloride ameliorates cognition dysfunction induced by sevoflurane anesthesia in rats. FEBS Open Bio 2019. doi:10.1002/2211-5463.12779. 